\title{
CRITICAL WATER CONTENT AND WATER STRESS COEFFICIENT OF SOYBEAN (lycine max [L.] Merr.) UNDER DEFICIT IRRIGATION
}

\author{
R.A. Bustomi Rosadi ${ }^{*}$, Afandi $^{*}$, Masateru Senge ${ }^{* *}$, Kengo Ito ${ }^{* *}$, and John T. Adomako ${ }^{* *}$
}

\section{Introduction}

Soybean is a very important commodity in Indonesia. About 1.3 million tons of soybeans is imported to meet $45 \%$ of its national consumption (Siswono, 2004). Water stress is a major constraint to increasing soybean yields in the tropical regions such as Indonesia. Soybean is normally planted at the end of the rainy season, therefore, water availability becomes a limiting factor to plant growth. Due to inadequate water resources the implementation of deficit irrigation seems beneficial. The objective of this research was to investigate the critical water content $\left(\theta_{c}\right)$ and water stress coefficient $\left(\mathrm{K}_{\mathrm{s}}\right)$ of soybean plant in the frame of optimum water management. The critical water content $\left(\theta_{c}\right)$ mentioned above can be estimated by the following equation.

$\theta_{\mathrm{c}}=\theta_{\mathrm{FC}^{-}} \mathrm{p}\left(\theta_{\mathrm{FC}}-\theta_{\mathrm{PWP}}\right)-----(1)$, and

$\mathrm{K}_{\mathrm{s}}$ from $\mathrm{ET}_{\mathrm{c} \text { adj }}=\mathrm{K}_{\mathrm{s}} \cdot \mathrm{ET}_{\mathrm{c}}$------ (2)

Where $\theta_{\mathrm{FC}}$ is moisture at field capacity and $\theta_{\mathrm{PWP}}$ is moisture at permanent wilting point; $\mathrm{ET}_{\mathrm{c}}$ is the crop evapotranspiration under standard condition.

\section{Materials and Method}

This research was done in a plastic house of the Faculty of Agriculture in University of Lampung from June to September 2000. Soybean cultivar Willis was used. Soil type was Ultisol. This research was conducted using a randomised complete block design with four replications. The treatments were 5 levels of water deficit (WD): WD1 (0-20)\%, WD2 (20-40)\%, WD3 (40-60)\%, WD4 (60-80) \% and WD5 (80-100)\% of total available water (TAW). Daily monitoring of soil water was done by gravimetric method. Variables evaluated in this research were plant height, leaf number, flower and pod number, dry weight of top and root biomass, yield, evapotranspiration rate, crop water requirement (CWR), water use efficiency (WUE), and yield efficiency (YE). Statistical analysis was done by the F-test at 5 and $1 \%$ significant levels, followed by LSD (Least Significant Different) test at the same level. The soil texture was clay. Soil water content at field capacity was $39.3 \%$ and wilting point was $21.6 \%$. Total available water (TAW) was $17.7 \%$ by volume. This amount was considered as $100 \%$ of total available water. Soybean seeds together with fertilizer were planted in black plastic containers (10 liters volume), which were filled of $7 \mathrm{~kg}$ air-dry soil. Evapotranspiration (ET) was calculated by gravimetric method. 2 seeds were planted on each container. The soybean plants were sprayed with insecticide to protect them from insect. The growth period of soybean plant was 85 days, and two weeks before harvesting, the irrigation was stopped.

\section{Results and Discussion}

The effects of water deficit on plant growth indicators are shown in tables 1 and 2, It can be observed from the tables that, water deficits WD1 and WD2 had no significant difference with regard to plant growth indicators throughout the growth period. On the other hand, significant differences in growth indicators were observed for water deficits WD3, WD4, and WD5 treatments from week IV.

From table 1, with the exception of WD3, which experienced stress at week VII, WD4 and WD5 showed stress from week V as far as the plant heights are concerned. However, in table 2, the plant leaves experienced stress from week IV for WD3, WD4, and WD5 treatments. It is clear that the growth performance indicators did not show water stress phenomenon at the same growth stage.

The yield of soybean plants were significantly affected under WD4 and WD5 treatments as shown in table 3. Further more, it can be seen that, the total biomass was also significant under WD3, WD4, and WD5 treatments.

Based on the explanation above, the fraction of the total available water, (p) at the point where the plants started experiencing stress could be taken as the average of WD3 (40-60\%), $\mathrm{p}=50 \%$ or 0.5 .From equation 1 above, the critical water content can be computed as $\left(\theta_{\mathrm{c}}\right)=[39.3 \%-0.5$ $(39.3 \%-21.6 \%)]=30.5 \%$.

Assuming that the evapotranspiration at WD1 (0-20\%) occurred under favorablel condition for plant growth, in which soil water content is near the field capacity, and there is no limitation for plant to meet the maximum evapotranspiration $\left(\mathrm{ET}_{\mathrm{m}}\right)$, the evapotranspiration $\left(\mathrm{ET}_{\mathrm{a}}\right)$ at WD1 is crop evapotranspiration $\left(\mathrm{ET}_{\mathrm{c}}\right)$, which means the evapotranspiration of plant under standard condition (Allen et. al., 1998). If evapotranspiration $\left(\mathrm{ET}_{\mathrm{c} \text { adj }}\right)$ of plant is measured under water stress, the $\mathrm{K}_{\mathrm{s}}$ value can be calculated by using equation 2 .

From table 4, it can be seen that the $\mathrm{K}_{\mathrm{s}}$ values of soybean plant varied depending on the growth stage and the AW deficit level. The $\mathrm{K}_{\mathrm{s}}$ values are the same as the values of $\mathrm{ET}_{\mathrm{a}} / \mathrm{ET}_{\mathrm{m}}$ when the plants were in stress condition $(*)$. Table 4 shows that the $\mathrm{K}_{\mathrm{s}}$ values tended to decrease week by week if there

*)Faculty of Agriculture , University of Lampung **) Faculty of Agriculture,Gifu University, Japan kevword : sovbean. critical water content. deficit irrigation 
is no change of AW deficit level at WD4 and WD5. But, the $\mathrm{K}_{\mathrm{s}}$ value at WD3 $(\mathrm{p}=0.5)$ varied from week IV to week VII with an average of 0.78 .

Table 3 showed that the WD3 treatment was the most efficient in yield efficiency $(0.021 \mathrm{~g} / \mathrm{mm})$.

Based on the equation as mentioned before, the average $\mathrm{K}_{\mathrm{y}}$ values is 0.85 (Table 5). Doorenboss and Kassam (1979), also found $K_{y}$ of soybean to be 0.85. It means that this experiment was good enough for calculating the $\theta_{c}$ and $K_{s}$.

Table 5 showed that the $\mathrm{K}_{\mathrm{y}}$ value of WD3 treatment was 0.61 , or $\mathrm{K}_{\mathrm{y}}<1$. It meant that WD3 treatment was in the deficit irrigation, and based on the crop water requirement and yield of soybean plant as mentioned previously, it can be concluded that the optimum yield of soybean plant with the highest of yield efficiency (0.021) was reached by deficit irrigation maintaining the soil water condition at the level $40-60 \%$ of $\mathrm{AW}$ deficit (WD3), with $\mathrm{p}=0.5, \theta_{\mathrm{c}}=30.5 \%, \mathrm{~K}_{\mathrm{s}}=0.78$, and can conserved $10.1 \%$ of water compared to the WD1. The optimum soybean yield was $7.88 \mathrm{~g} / \mathrm{pot}$ and crop water requirement was $372 \mathrm{~mm}$.

\section{Conclusion}

The soybean plant started to experience stressed from week IV with $(\mathrm{p})=0.50$, and $\theta_{\mathrm{c}}=30.5 \%$. The yield response factor of soybean $\left(\mathrm{K}_{\mathrm{y}}\right)$ was 0.85 . The optimum yield of soybean plant was reached by deficit irrigation at the level of 40-60\% of AW deficit, which conserved $10.1 \%$ of water, and the value of $\mathrm{K}_{\mathrm{s}}$ was 0.78 . The optimum yield of soybean plant was $7.88 \mathrm{~g} /$ pot and crop water requirement was $372 \mathrm{~mm}$.

\section{References}

Allen, R.G., LS. Pereira, d. Raes, and M. Smith.1998. Crop Evapotranspiration. Irrigation and Drainage Paper no.56, FAO, Rome, Italy.301.

Doorenbos, J. and A.H. Kassam. 1979. Yield Response to Water. FAO, Roma: 1-57.

Siswono. Y. 2004. Development in Agriculture continuous to retret. Kompas. January 8, 2004: 1.

Table 1. The effect of WD to the plant height $(\mathrm{cm})$, flower and pod number

\begin{tabular}{|c|c|c|c|c|c|}
\hline \multirow{2}{*}{$\begin{array}{l}\text { WD deficit } \\
\text { level }(\%)\end{array}$} & \multicolumn{3}{|c|}{ Plant height } & Flower & Pod \\
\hline & $\begin{array}{l}\text { Week } \\
\text { V }\end{array}$ & $\begin{array}{l}\text { Week } \\
\text { VI }\end{array}$ & $\begin{array}{l}\text { Week } \\
\text { VII }\end{array}$ & $\begin{array}{l}\text { Week } \\
\text { VI }\end{array}$ & Week VII \\
\hline WD1 ( 0-20) & $67 \mathrm{a} a$ & $96 \mathrm{a} a$ & $97 \mathrm{a} a$ & $25 \mathrm{a} a$ & $23 \mathrm{a} \quad \mathrm{a}$ \\
\hline WD2 (20-40) & $58 \mathrm{a} a$ & $87 \mathrm{a} a$ & $97 \mathrm{a} a$ & 23 a a & $15 \mathrm{a} a$ \\
\hline WD3 (40- 60) & $56 \mathrm{aab}$ & 81 a a & $85 \mathrm{~b} \mathrm{~b}$ & $23 \mathrm{a} a b$ & $15 \mathrm{ab} a b$ \\
\hline WD4 (60-80) & $38 \mathrm{~b} \mathrm{~b}$ & $52 \mathrm{~b} \mathrm{~b}$ & $58 \mathrm{c} \mathrm{b}$ & $9 \mathrm{bb}$ & $6 \mathrm{bcb}$ \\
\hline WD5 (80-100) & $37 \mathrm{~b} \mathrm{~b}$ & $48 \mathrm{~b} \mathrm{~b}$ & $51 \mathrm{cb}$ & $9 \mathrm{~b} \mathrm{~b}$ & $5 \quad c \quad b$ \\
\hline BNT (\%) & 51 & 51 & 51 & 51 & $\begin{array}{ll}5 & 1\end{array}$ \\
\hline
\end{tabular}

Remarks: numbers followed by the same letters vertically were not significant different
Table 2. The effect of WD to the leaf number

\begin{tabular}{|c|c|c|c|c|}
\hline $\begin{array}{l}\text { WD deficit } \\
\text { level (\%) }\end{array}$ & $\begin{array}{c}\text { Week } \\
\text { IV }\end{array}$ & $\begin{array}{c}\text { Week } \\
\text { V }\end{array}$ & $\begin{array}{c}\text { Week } \\
\text { VI }\end{array}$ & $\begin{array}{c}\text { Week } \\
\text { VII }\end{array}$ \\
\hline WD1 $(0-20)$ & $15 \mathrm{a} \mathrm{a}$ & 32 a $\quad$ a & 57 a a & $78 \mathrm{a} a$ \\
\hline WD2 (20-40) & $14 \mathrm{a} \mathrm{a}$ & $30 \mathrm{ab}$ a & $50 \mathrm{ab} a$ & 71 a a \\
\hline WD3 (40-60) & $11 \mathrm{~b} \mathrm{~b}$ & $25 \mathrm{~b}$ ab & $46 \mathrm{~b} \quad \mathrm{a}$ & $64 \mathrm{a} \mathrm{a}$ \\
\hline WD4 (60-80) & $11 \mathrm{~b} \mathrm{~b}$ & $18 \mathrm{c} \mathrm{bc}$ & $26 \mathrm{c} \mathrm{b}$ & $29 \mathrm{~b} \mathrm{~b}$ \\
\hline WD5 $(80-100)$ & $10 \mathrm{~b} \mathrm{~b}$ & $16 \mathrm{c} \mathrm{c}$ & $20 \mathrm{c} \mathrm{b}$ & $26 \mathrm{~b} \mathrm{~b}$ \\
\hline LSD (\%) & 51 & $\begin{array}{ll}5 & 1 \\
\end{array}$ & $\begin{array}{ll}5 & 1 \\
\end{array}$ & 51 \\
\hline
\end{tabular}

Remarks: The same as table 1.

Table 3. The effect of WD to total biomass, yield, CWR, WUE, and YE.

\begin{tabular}{|c|c|c|c|c|c|}
\hline $\begin{array}{c}\text { WD } \\
\text { evel } \\
(\%)\end{array}$ & $\begin{array}{c}\text { Total } \\
\text { Biomas } \\
(\mathrm{g})\end{array}$ & $\begin{array}{c}\text { Yield } \\
(\mathrm{g})\end{array}$ & $\begin{array}{c}\text { CWR } \\
(\mathrm{mm})\end{array}$ & $\begin{array}{c}\text { WUE } \\
(\mathrm{g} / \mathrm{mm})\end{array}$ & $\begin{array}{c}\text { YE } \\
(\mathrm{g} / \mathrm{mm})\end{array}$ \\
\hline WD1 & $46 \mathrm{a}$ a & $9.13 \mathrm{a}$ a & $479 \mathrm{a}$ a & 0.096 & 0.019 \\
\hline WD2 & $45 \mathrm{a}$ a & $9.08 \mathrm{a}$ a & $456 \mathrm{a}$ a & 0.098 & 0.020 \\
\hline WD3 & $35 \mathrm{~b} \mathrm{~b}$ & $7.88 \mathrm{a} \mathrm{b}$ & $372 \mathrm{~b} \mathrm{~b}$ & 0.095 & 0.021 \\
\hline WD4 & $15 \mathrm{c} \mathrm{c}$ & $3.13 \mathrm{~b} \mathrm{~b}$ & $246 \mathrm{c} \mathrm{c}$ & 0.059 & 0.013 \\
\hline WD5 & $11 \mathrm{c} \mathrm{c}$ & $2.68 \mathrm{~b} \mathrm{~b}$ & $223 \mathrm{c} \mathrm{c}$ & 0.051 & 0.012 \\
\hline LSD(\%) & 51 & $5 \mathrm{r}$ & $5 \mathrm{c}$ & & \\
\hline
\end{tabular}

Remarks: The same as table 1 .

Table 4. The Ratio $\mathrm{ET}_{\mathrm{a}} / \mathrm{ET}_{\mathrm{m}}$, and $\mathrm{K}_{\mathrm{s}}$

\begin{tabular}{|c|c|c|c|c|c|c|c|}
\hline \multirow{2}{*}{$\begin{array}{l}\text { WD } \\
\text { level }\end{array}$} & \multicolumn{7}{|c|}{ Week } \\
\hline & $\mathrm{I}$ & II & III & IV & $\mathrm{V}$ & VI & VII \\
\hline WD1 & 1 & 1 & 1 & 1 & 1 & 1 & 1 \\
\hline WD2 & 0.94 & 0.95 & 0.97 & 0.90 & 0.98 & 0.87 & 0.93 \\
\hline WD3 & 0.92 & 0.87 & 0.95 & 0.78 & 0.86 & 0.78 & 0.71 \\
\hline WD4 & 0.89 & 0.87 & 0.80 & 0.67 & 0.67 & 0.43 & 0.39 \\
\hline WD5 & 0.81 & 0.85 & 0.79 & 0.62 & 0.67 & 0.41 & 0.34 \\
\hline $\begin{array}{l}\mathrm{ET}_{\mathrm{m}} \\
(\mathrm{mm})\end{array}$ & 2.6 & 1.41 & 1.88 & 3.9 & 4.6 & 9.6 & 13.2 \\
\hline
\end{tabular}

Assume: The bold number is in stress condition. $\mathrm{K}_{\mathrm{s}}$ is $\mathrm{ET}_{\mathrm{a}} / \mathrm{ET}_{\mathrm{m}}$ value in stress condition or $\mathrm{ET}_{\mathrm{c} \text { adj }} / \mathrm{ET}_{\mathrm{c}}$.

Table5.The yield, ET, 1- $\mathrm{Y}_{\mathrm{a}} / \mathrm{Y}_{\mathrm{m}}, 1-\mathrm{ET}_{\mathrm{a}} / \mathrm{ET}_{\mathrm{m}}$, and Ky

\begin{tabular}{|c|c|c|c|c|c|}
\hline $\begin{array}{c}\text { WD deficit } \\
\text { level (\%) }\end{array}$ & $\begin{array}{l}\text { Yield } \\
(\mathrm{g})\end{array}$ & $\begin{array}{c}\text { ET } \\
(\mathrm{mm})\end{array}$ & $\begin{array}{c}1- \\
Y_{a} / Y_{m}\end{array}$ & $\begin{array}{c}1- \\
\mathrm{ET}_{\mathrm{a}} / \mathrm{ET}_{\mathrm{m}}\end{array}$ & Ky \\
\hline WD1 ( $0-20)$ & 9.13 & 479 & - & - & - \\
\hline WD2 (20-40) & 9.08 & 458 & 0.055 & 0.045 & 0.12 \\
\hline WD3 (40-60) & 7.88 & 372 & 0.132 & 0.224 & 0.61 \\
\hline WD4 (60-80) & 3.13 & 246 & 0.659 & 0.486 & 1.35 \\
\hline \multirow[t]{2}{*}{ WD5 (80-100) } & 2.68 & 223 & 0.703 & 0.535 & 1.32 \\
\hline & & & & Average & 0.85 \\
\hline
\end{tabular}

Remarks: It is assumed that ET and yield at WD1 is the max. ET $\left(\mathrm{ET}_{\mathrm{m}}\right)$ and max. yield $\left(\mathrm{Y}_{\mathrm{m}}\right)$

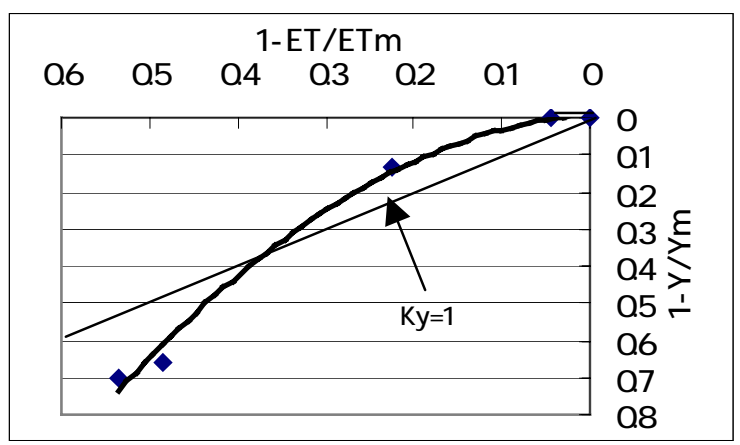

Figure 1. The relation between relative decreased (1-Ya/Ym) and relative ET (1-ETa/ETm) 